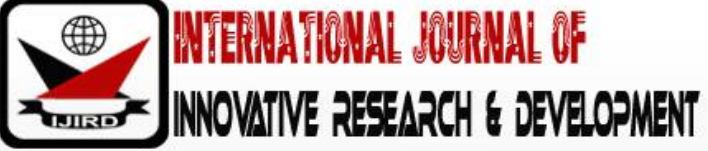

ISSN 2278 - 0211 (Online)

\section{Foreign Direct Investment Spillover and the Size of Trade Growth in West African Monetary Zone}

\begin{tabular}{|c|}
\hline Chukwuemeka Amaefule \\
Doctoral Candidate, Department of Economics, \\
University of Port Harcourt, Nigeria \\
Akeem Shoaga \\
Researcher, University of Port Harcourt, Nigeria \\
\hline
\end{tabular}

\begin{abstract}
:
The aim of this study is to examine the impact of Foreign Direct Investment(FDI) spillover measured by increase in FDI inflow and decrease in FDI inflow on the size of trade growth proxy by trade (\% GDP) in Gambia, Ghana, Nigeria, and Sierra Leone from 1970 to 2017. The study employed Non-linear ARDL framework. The result showed that increase in FDI inflow is necessary to cause trade growth in Sierra Leone in the long-run, and is not an effective source of capital flow in trade growth in Gambia, Ghana, and Nigeria. Also, decrease in FDI inflow generated a decline in the long-run trade size growth in Gambia, Ghana, Nigeria and positive impact on trade size growth in Sierra Leone. Thus, FDI spillover effects vary from country to country in selected West African Monetary Zone (WAMZ) country. There should be serious FDI inflow based corporate governance mechanisms that will coordinate the effective utilization and deployment of FDI inflows to core areas of economic need. FDI inflow should be meant to find those sectors that can optimally use it to enhance productivity.
\end{abstract}

Keywords: FDI spillover, trade size growth, WAMZ

\section{Introduction}

Blomstrom and Kokko (1998) reports that the spillover of FDI can be estimated by its impact on productivity and the competitive drive it offers in the recipient country. Therefore, the global imperativeness of Foreign Direct Investment (FDI) on trade size remains topical. This study particularly considered the effectiveness of FDI as an instrument of globalization on trade size in West African Monetary Zone (WAMZ).The major argument in the nexus between spillover effects FDI has on trade size seems ambiguous on domestic economy. Thus, the connection between trade growth and FDI is complex (Fontagne, 1999). FDI is instrumental in the movement of producer-driven network. In other words, countries with high FDI inflow had positive direct export performance (siteresources.worldbank.org).Obviously, trade contributes to the external reserve of countries; robust net export trade volume clearly defines the capacity of countries to earn foreign exchange. Through the foreign exchange earned from trade, the more positive current account portrays the healthiness of a country's trade position.

The imperativeness of FDI can be accessed by its effectiveness to cause spillover which could be positive, negative or neutral. Spillover generates technological transfers which affect growth (Sjoholm, 1999; Blomstrom et al., 2000; UNCTAD, 2000). The generated technological effect of FDI can be seen on the role of its impact on local enterprises through vertical and horizontal linkage (Lim, 2001; Zhnag, 2001; Smarzynska, 2002), its impact to improve R and D across borders (Hanson, 2001; Blomstrom and Kakko, 1998) and foster integration (Mencinger, 2003). However, the spillover effect of FDI depends on financial system (Reisen and Soto, 2001), host country's absorptive and social capacity utilization (Carkovic and Levine, 2002). Also, in a related study, the dimension of the spillover can be positive (Alfaro, 2003), weak (Hanson, 2001), negative (Gorg and Greenaway, 2003) and could improve competition (Lee and Tcha, 2004; Driffield and Taylor, 2000; Vu, 2007; OECD, 2002).Caves (1996) clearly delineates positive spillovers to includes gains in productivity, transfer of technology, introduction of innovative processes, managerial skills and know-how in the domestic economy, employee training, international production network and access to market.

FDI and indeed other forms of external finance remains an important threshold to access the functionality of globalization and financial liberalization i.e. capital liberalization policy of WAMZ which is traceable to World Bank/ Structural Adjustment Programme of 1986 in Africa. SAP 1986 historically justified FDI flow as source that could be leverage upon to restructure and diversify the productive base of West African countries. Thus, through the strategies adopted in SAP 1986 and presently Banjul Action Plan of 2009 which focused on eliminating restriction on capital movement across border to enhance financial intermediation, FDI can therefore be looked upon as a source of capital finance. Caprio and Demirguc-Kunt (1998) posits that finance positively impact growth. In other words, finance provides 
critical leverage for growth (Demetriades and Hussein, 1996). FDI as a form of finance capital finance generates growth impact (Watchel, 2003).

\subsection{Statement of Problem}

FDI inflow to Africa grew by 11 percent to US\$ 46 billion in 2018. The regional classification is viz; 7 percent rise in North Africa to the tune of US\$14 billion; FDI inflows into Sub-Saharan and Southern Africa increased by 13 percent to US\$32 billion. FDI inflows to East Africa stood at US\$9 billion and dropped in West Africa by 15 percent to US\$ 9.6 billion (UNCTAD, 2019). Thus, while the impact of FDI seems ambiguous on Emerging and Developing Economies (EMDE), developing countries vigorously tend to enact policies to attract FDI inflow. WAMZ is not an exception; WAMZ has put in place clear-cut strategies to attract FDI in order to allocate same to drive regional growth. FDI inflows in West African seems fluctuatory, could it be responsible for the WAMZ inability to attain convergence? Scholars had rightly reported that FDI generate spillover, does FDI has positive spillover on trade size in WAMZ?

It is therefore imperative to properly explore the effectiveness of FDI viz-a-viz FDI spillover on WAMZ to clearly situate how positive inflow in FDI and decrease inflow in FDI impact trade growth. The motivating question therefore becomes: does FDI spillover affect the size of trade growth in West African Monetary Zone? The term spillover is used to unravel the positive impact and negative impact of FDI inflows into WAMZ.

\subsection{Aim and Objective}

The aim of this study is to empirically investigate the FDI spillover effect on the size of trade growth in West

African Monetary Zone from (WAMZ) 1970 to 2017. Specifically, this study seeks to

- Identify the trend in FDI flow and trade (\%GDP) in selected WAMZ countries;

- Examine the impact of positive FDI inflow on the size of trade growth in selected WAMZ countries;

- Investigate the effectiveness of negative FDI inflow on the size of trade growth in selected WAMZ countries.

\section{Literature Review}

\subsection{Theoretical Literature}

Endogenous economic growth theory developed support the internal transmission process of FDI on growth. FDI as a component of technology is regarded as an endogenous variable. The proponents of new growth theory are viz; Lucas (1998) human capital, Barro (1991) public infrastructure, Romer (1990) incentives to innovate, and Barro and Sala-imartins (2004) technological diffusion. The compelling advantage which this theory offers to explain the FDI spillover effect is that lag FDI, previous FDI could be term endogenous and has the capacity to propel the economy over the longrun. Basically, FDI spillover could be seen in the postulations of Borenztein, De-Gregorio and Lee (1998) cross border transfers of technology from region of high innovative countries to a region of low innovative countries. Hence through the process of technology diffusion FDI accelerate growth. Then the link between the theoretical frameworks of this study is to determine the endogenous FDI effect in its previous state (lagged FDI spillover effect) to generate trade growth measure by trade $\%$ of GDP.

\subsection{Empirical Literature}

Belloumi (2014) in a bound ARDL estimation from 1970-2008 found a long-run relationship between trade and FDI in Tunisia. However, the result from granger causality test revealed that no significant granger causality between FDI to growth, economic growth to FDI, trade to economic growth, and economic growth to trade in the short-run. The study showed that positive FDI spillover do not exist in Tunisia ceteris paribus. Fontagne (1999) found that FDI stimulates export growth and the investment is complementary to trade which differ from country to country. In a granger causality test Simionescu (2014) found short-run causality between FDI and exports and FDI and imports for G7 countries and longrun unidirectional causal relationship between FDI and trade. Sakyi and Egyir (2017) using GMM supports Bhagwati hypothesis which predicts that trade (exports) and FDI interaction generates per se spillover on growth. From 1990-2014 FDI inflow affected trade for 45 African countries which further significantly affected growth. Aizenman and Noy (2005) found 81 percent linear feedback causality hence FDI causality to trade is 50 percent, and trade to FDI is 31 percent. Sakyi, Commodore and Opoku (2015) found that FDI and trade interaction foster growth in Ghana validating Bhagwati hypothesis.

Lin and Lin (2010) predict that inward FDI, outward FDI, imports, and exports have positive influences on firm's innovative activities. Also, FDI outward, and FDI inward exhibits strongly positive effects in generating product innovation. Zaman et al (2018) adopted a fixed effect model and Pooled OLS the result showed that higher openness of trade has significant positive impacts on FDI inflows for India, Iran, and Pakistan. Nguyen, D., T. Anh; and C. Phuong (2012) in Vietnam study found the following results employing granger causality test that one way causality linkage between trade and FDI, and found bi-casual linkage between FDI and import, and in a gravity model showed that bilateral trade flows is determined by economic size and minimally affected by geographical distance.

\subsection{Justification for the Study: FDI, Trade Size and WAMZ External Reserves}

The justification for this empirical study is based on the findings of a linkage between trade and external reserves established in Nteegah and Okpoi (2017). It is based on this connection, that the study considers trade as a direct causation to external reserves, a component in WAMZ's Macroeconomic Convergence Criteria (MCC). One of the primary targets in MCC is to achieve external reserves that would cover 3 months imports required for the establishment of 
Economic and Monetary Union (EMU). Thus, our central justification of this study is built on the fact that robust trade growth could be imperative to achieving long-run convergence in external reserves greater than 3 months imports in WAMZ.

\subsection{Evaluation and Adoption of Non-linear ARDL}

The literature is silent on the implication of the impact of a decrease in FDI inflow and increase on FDI inflow on trade in West Africa. This study fills this gap by adopting Non-linear ARDL that captures the effect of positive FDI inflow (increase) and negative FDI inflow (decrease) on trade, in selected West African Monetary Zone.

\section{Method of Study}

The research designed adopted for this study is exposed facto research design. The time series data from World Bank were employed in an NARDL framework developed by Shin, Yu, and Green-wood (2011). NARDL provides us with the instrument to measure the impact of increase and decrease impact of a given economic variable on target variable. To properly access spillover in FDI it is therefore important we select instrument that offers us the leverage to undertake this task. Hence the selection of NARDL to study the impact of FDI spillover on trade in WAMZ. NARDL is a technique that is used to study asymmetric relationship among a given model. It is a lagged autoregressive scheme model that capture inter-temporal effect of a given variable over a period of time. It is based on the ambiguous impact of FDI on EMDE this study seeks to examine the impact of FDI on trade size in selected West African Monetary Zone from 1970 to 2017. Data sourced from World Bank is employed to study the spillover impact of FDI on trade. However, FDI spillover is examined based on the significant impact of FDI on key trade indicator in Ghana, Gambia, Sierra Leone, and Nigeria.

It is based on the linkage between trade and external reserves established in Nteegah and Okpoi (2017) which submit that foreign trade possesses direct implication on foreign reserves. Thus, it therefore significant to delve into the dynamics of FDI as a source of finance to improving external trade capacity of selected West African Monetary Zone's countries. WAMZ has achievement of external reserves greater than 3 months import as a target in its Macroeconomic and Convergence Criteria (MCC) to adopt Economic and Monetary Union (EMU). Therefore, it is incumbent to study trade as direct link to the achievement of external reserves.

\subsection{Model Specification}

The NARDL of Shin, Yu, Greenwood-Nimmo (2011) was modified by Dhaoui and Bacha (2017, p.5) as

$T V_{t}=\alpha_{0}+\alpha_{1} S P_{t}^{+}+\alpha_{2} S P_{t}^{-}+\alpha_{3} S E N T_{t}^{+}+\alpha_{4} S E N T_{t}^{-}+e_{t}$

Where TV=Trading volume,

$\mathrm{SP}=$ Stock Price taken in natural logarithm, SENT is a proxy for investors sentiment. From the foregoing insight into asymmetric NARDL, with particular reference to the modified version put forward by Dhaoui and Bacha (2017) in equation (1). Further modification will be carried out to reflect the major objective of this study.

$\Delta \operatorname{LnTRD}_{m 1-4 t}=A+\beta_{0} \operatorname{LnTRD}_{t-1}+\beta_{1}$ LnFDI $_{t-1}^{+}+\beta_{2} \operatorname{LnFDI}_{t-1}^{-}+\beta_{3} \operatorname{LnODA}_{t-1}^{C V}+\beta_{5} \operatorname{LnIBRD}_{t-1}^{C V}+\sum_{i=1}^{\rho} \theta \Delta \operatorname{LnTRD}_{t-1}+$ $\sum_{i=0}^{\sigma}\left(\gamma_{i}^{+} \Delta L n F D I_{t-1}^{+}+\gamma_{i}^{-} \Delta L n F D I_{t-1}^{-}\right)+\mu_{t}$

$\operatorname{LnFDI}_{t}^{+}=\sum_{i=1}^{t} \Delta F D I_{t}^{+}=\sum_{i=1}^{t} \max \left(\triangle F D I_{t}, 0\right)$ and

$\operatorname{Ln} F D I_{t}^{-}=\sum_{i=1}^{t} \Delta F D I_{t}^{-}=\sum_{i=1}^{t} \min \left(\triangle F D I_{t}, 0\right)$

where TRD=Trade (\% GDP), FDI+ positive FDI inflow, FDI- negative FDI inflow, ODA official development Assistance, IBRD loans from International Bank for Reconstruction and Development, $\mathrm{cv}=$ controlled variable.

\section{Results and Discussion}

FDI and growth trend in Gambia, Ghana, Nigeria and Sierra Leone are thus;

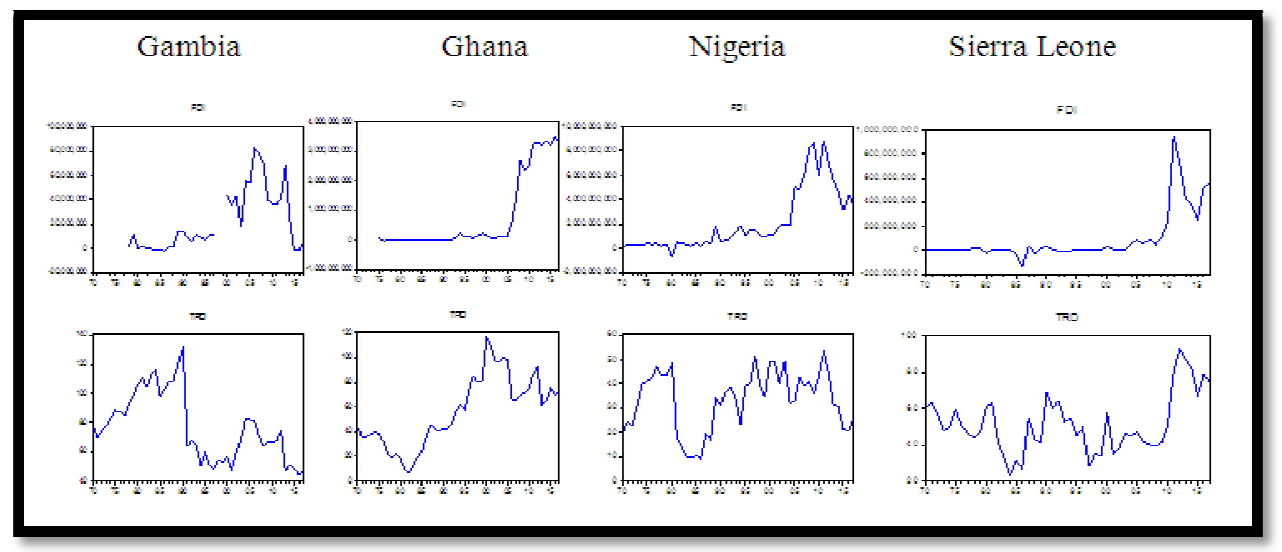

Figure 1

The figures above showed FDI and Trade measured by Trade (\%GDP) across selected WAMZ countries. Also, the graph trend behaviour for each variable is represented in multiple graphs. The countries are Gambia, Ghana, Nigeria, and Sierra Leone. The graph showed a highly trended behaviour. Hence the need to conduct a first difference stationary test. The variables using ADF unit root test were I(1). 
In this study we employed NARDL framework to access the FDI spillover impact on trade in selected African countries such as Gambia the, Ghana, Nigeria, and Sierra Leone from 1970-2017. The results obtained are presented in table 1. We showed a long run feature of the asymmetric relationship between FDI spillover measured by increase and decrease FDI inflow on trade across selected African countries.

\begin{tabular}{|c|c|c|c|c|c|}
\hline & & GAMBIA & GHANA & NIGERIA & SIERRA LEONE \\
\hline Bound Test & Fstat & $2.034^{*}$ & 7.382 & 7.263 & 18.37 \\
\hline$\% 5$ & I0 & 2.86 & 2.86 & 2.86 & 2.86 \\
\hline & I1 & 4.01 & 4.01 & 4.01 & 4.01 \\
\hline Cointeg EQ & Coeffient & -0.95129 & -1.10705 & -1.78515 & -1.4200 \\
\hline LongRunForm & Pvalue & $(0.0134)$ & $(0.0000)$ & $(0.0000)$ & $(0.0000)$ \\
\hline & LnFDIpos & -0.13965 & -0.05378 & -0.1613 & 0.02959 \\
& & $\left(0.0718^{*}\right)$ & $(0.0101)$ & $\left(0.118^{*}\right)$ & $\left(0.3270^{*}\right)$ \\
\hline & LnFDIneg & -0.17377 & -0.16301 & -0.2427 & 0.0171 \\
& & $\left(0.0909^{*}\right)$ & $(0.0068)$ & $\left(0.0747^{*}\right)$ & $\left(0.6789^{*}\right)$ \\
\hline & LnODA & -0.92713 & -0.13011 & 0.173272 & -0.20958 \\
& & $\left(0.3350^{*}\right)$ & $\left(0.3273^{*}\right)$ & $(0.0146)$ & $(0.0030)$ \\
\hline & LnIBRD & 0.10566 & -0.00291 & -0.18493 & 0.09886 \\
& & $\left(0.1445^{*}\right)$ & $\left(0.9565^{*}\right)$ & $\left(0.0818^{*}\right)$ & $\left(0.0699^{*}\right)$ \\
\hline Diagnostics & Ramsey RT & $0.0216^{*}$ & 0.6868 & 0.4976 & 0.5203 \\
\hline Pvalues & Stability & & & & 0.4100 \\
\hline & HTBPG & 0.7056 & 0.4312 & 0.9680 & 0.7067 \\
\hline & LMT & 0.3472 & 0.6973 & 0.3870 & 0.5198 \\
\hline & Normality & 0.2255 & 0.6241 & 0.7620 & WB \\
\hline & CUMSUM & WB & WB & WB & WB \\
\hline & CUMSUM & WB & WB & WB & $(1,0,2,0,0)$ \\
\hline SQUARES & & & & $(2,3,3,4,1)$ & \\
\hline
\end{tabular}

Table 1: Long Run Coefficients Estimation of FDI Positive and Negative

Spillover on Size of Trade in NARDL Framework

Source: $\mathrm{E}$ views 9, NWB=Not Well Behaved; WB=Well Behaved

The results present an asymmetric result of increase (positive FDI inflow) and decrease (negative FDI inflow) on Trade size in selected African countries. Increase in FDI inflow caused negative spillover on the size of trade growth in Gambia, Ghana, and Nigeria. Also, increase in FDI Inflow generated a positive impact on the size of trade growth in Sierra Leone. It is imperative to note that increase in FDI spillover do not have any significant effect on size of trade growth across selected African countries. Secondly, decrease in FDI spillover effect caused a corresponding decline in trade size in Gambia, Ghana, and Nigeria, and as well as positive impact on Sierra Leone. The significant impact of decrease in FDI inflow occurred only in Ghana. Additionally, ODA inflows and Loans from IBRD were used as complementary inflows. Thus, loans from IBRD had positive impact on trade size in Gambia and Sierra Leone; and negative impact

These results imply that FDI inflow increase is required to boost trade growth in Sierra Leone in the long-run. Also, FDI inflow could generate negative impact on the size of trade growth in Gambia, Ghana, and Nigeria. Hence could not be an important element of trade growth. Similarly, what happens to trade growth in selected when FDI inflow declines? From the results, the long-run outcomes connote that trade size would be affected in Gambia, Ghana, and Nigeria, but could be healthy for Sierra Leone.

\section{Conclusion and Policy Implication}

The impact of FDI inflow spillover differs across WAMZ. Hence FDI inflow in the long-run can stimulate trade growth given the right environment. The study is consistent with Fasanya and Adegbemi (2012) and Fontagne (1999) that the impact of FDI differs across sectors. The degree of FDI spillover could have materialised in countries where increase in FDI inflow showed negative effect. Thus, generally the impact of FDI spillover effect across WAMZ is said to be weak (Hanson, 2001). So, in an attempt to properly situate spillover effect of FDI on trade capacity in WAMZ viz-a-viz external reserves MCC target, it is clear that the study by Sjoholm (1999); Blomstrom et al. (2000), UNCTAD, 2000) technological linkage Lim(2001), Zhnag (2001), Smarzynska (2002), Caves (1996) do not hold in WAMZ to a greater extent. Also, we can conclude that the dynamic of FDI spillover holds in such that FDI inflow has positive impact on Sierra Leone which is consistent with (Alfaro, 2003),negative FDI inflow spillover in Gambia, Ghana, and Nigeria is consistent with the findings of (Gorg and Greenaway, 2003). Countries of Gambia, Ghana, and Nigeria should implement strategic sectoral utilization policy that would guarantee FDI inflow maximally contributes to trade.

\section{Recommendation}

Based on the conclusion we therefore provide possible suggestion to WAMZ attainment of long-run convergence;

- Effective policies to attract growth targeted FDI inflow is required into WAMZ and Sierra Leone 
- Authorities in WAMZ should implement clear cut trade policies to effectively attract the sufficient FDI inflows

- FDI inflow might not affect trade in Gambia, Ghana, and Nigeria, and such policy makers should come up with appropriate policy kit to ensure that FDI inflow affect trade size growth in the long-run.

- WAMZ should aggressively adopt import reduction strategy. There should be a deliberate enactment of physical measures to directly exterminate importation of finished raw produces into WAMZ.

\section{References}

i. Ayanwale, A. B. (2007). FDI and Economic Growth: Evidence from Nigeria. AERC Research paper 165 African Economic Research Consortium Nairobi

ii. Aizenman, J. and I., Noy (2005). FDI and Trade-Two-way linkages. NBER working papers series 11403

iii. Alfaro Laura (2003). FDI and growth: Does the sector matter. Harvard Business School, 1-31.

iv. Aremu J. A. (1997). Foreign Private Investment: Issues, determinants and performance, A paper presented at a workshop on foreign investment policy and practice, organized by the Nigeria Institute of Advance legal Studies, lagos, March

v. Balasubramanyam, V. N., M. Salisu, and David Sapsford (1996). FDI and Growth in EP and IS countries. Economic Journal Royal Economic Society Vol106(434), pp93-105

vi. Barro Robert J. (1991). Economic Growth in a cross section of countries. Quarterly Journal of Economics. Vol.106, No 2, (May1991) pp407-443

vii. Barro Robert J. and Xavier Sala-i-martins (2004). Economic Growth. second edition. The MIT press, Massachusetts

viii. Barry Frank (2000). EU accession prospective FDI flows to CEE countries: A view from Ireland, August 2002. EUfunded research project on labour Market Effects of European FDI (HSPE-CT99-00017).

ix. Bello Ajide and Oluwatosin Adeniyi (2010). FDI and the environment in developing economies: Evidence from Nigeria. Environmental research Journal 4;291-297

x. Belloumi, M. (2014). The relationship between trade, FDI, and economic growth in Tunisia: An application of ARDL Economic System Vol 38, Iss 2, pp. 269-287

xi. Blomstrom, Magnus and Fedrik Sjoholm (1998). Technology transfer and Spillovers? Does local participation with multinational Matter? NBER working papers 6816 National bureau Economic Research Inc.

xii. Blomstrom, Magnusand Kokko, Ari (2000). Outward investment, Employment and wages in Swedish Multinationals, Oxford Review of Economic Policy, Oxford University Press, Vol. 16(3) pp76-89

xiii. Borenztein Eduardo, Jose De-Gregorio and Jong Wha Lee (1998). How does FDI affect Growth? Journal of International Economics June 115-135, NBER working paper No 5057

xiv. Caprio Gerard and Demirguc-Kunt Asli (1998). The role of long-term finance; theory and evidence. The world Bank Researcher Observer vol 13, no 2 (August 1998) pp.171-89. http:/ / documents.worldbank.org/ curated/ en807651468152710192/ The-role-of-long-term-finance-theory-andevidence

xv. Carkovic V. Maria and Ross Levine (2002). Does FDI accelerate economic growth? U of Minnesota Department of Finance Working paper 23 June (2002).

xvi. Caves E. Richard (1996). Multinational Enterprise and Economic Analysis. Cambridge University Press 26 Jan (1996)

xvii. Demetriades Panicos and Khaled A. Hussein (1996). Does financial development cause economic growth? Timesseries from 16 countries. Journal of Development Economics, 1996, Vol. 51, Iss 2, pp387-411

xviii. Driffield N, and K Taylor (2000). FDI and the labour market: A review of the evidence and policy implications. Oxford Review of Economic Policy Vol. 16 Iss.3 September (2000), pp 90103https:/ / doi.org/ 10.1093/ oxrep/ 16.3.90

xix. Ekpo A. H. and F. Egwaikhide (1998). Private investment and external debt: Is the debt Overhang Hypothesis relevant to Nigeria. Nigeria Journal of Economic and Social Sciences Vol. 40, No.1, pp.87-100

xx. Fontagne, L. (1999). Foreign Direct Investment and International Trade: Complement or Substitutes? OECD science, technology and industry working papers 1999/ 03

xxi. Fredrik Sjoholm (1999). Technology gap, competition and spillovers from direct investment: Evidence from establishment data. The Journal of Development Studies Vol $36 \quad$ (1999), Iss. 1. https:/ / doi.org/ 10.1080/ 00220389908422611

xxii. Funke Nobert and Saleh M. Nsouli, (2003). The New Partnership for Africa's Development (NEPAD): Opportunities and Challenges. Researchgatehttps// 10.

xxiii. Gorg Holger and David Greenaway (2003). Much Ado about Nothing? Do domestic firms really benefit from FDI? The World Bank Research Observer Vol 19, Iss 2, September 2004, pp 171-197 (September, 2004) https:/ / doi.or/ 10.10.1093/ wbro/ lkh019 and IZADiscussion paper No.994 November, 2003

xxiv. Hanson Gordon H (2001). Should countries Promote Foreign Direct Investment? G-24 Discussion paper Series UNCTAD No9 February (2001)

xxv. Ingram, J. C. (1973). The case for European Monetary Integration, Princeton Essays in International Finance 98. Princeton University Press: Princeton, N.J.

xxvi. Ismail O. Fasanya and Adegbemi B. O. Onakoya (2012). Does Foreign Aid Accelerate economic growth? An empirical analysis for Nigeria International Journal of Economics and Financial Issues, Econjournals Vol. 2(4) pp 423-431 
xxvii. Khan Mohammad Arshad (2007). FDI and Economic Growth: The role of domestic financial sector. Finance Working Paper 222205 East Asian Bureau of Economics Research

xxviii. Khan Shiraz and Mehboob Farhan (2014). Impact FDI on GDP: An Analysis of Global economy on Production function. MPRA paper_55352.pdf

xxix. Lee Minsoo and Moonjoong Tcha (2004). The colour of money: The effects of FDI on economic growth transition economies. Review of World Economics June (2004), Vol 140 Issue 2, pp211-229

xxx. Lim Ewe-Ghee (2001). Determinants of, and the Relation Between, Foreign Direct investment and Growth: A summary of the recent literature. IMF working papers No.01/175, November 1

xxxi. Lin, H. and E. S. Lin (2010). FDI, trade, and product innovation: Theory and Evidence. Southern Economic Journal 77(2):434-464

xxxii. Lucas, R. E. (1990). Why doesn't capital flow from rich to poor countries? American Economic Review 80 (2) $92-96$

xxxiii. $\quad$ McKinnon, R. I. (1963). Optimum Currency Areas. Am. Econ. Rev. 53(1963)pp.717-725

xxxiv. Mencinger Joze (2003). Does FDI always enhance economic growth? Kyklos Vol 56 Iss.4. https:/ / doi.org/ 10.1046/j.0023-5962.2003.00235.x

xxxv. $\quad$ Mundell, R. A. (1961). A theory of Optimum Currency Areas. American Economic Review 51, 657-665

xxxvi. Najat Nassor Suleiman, Ranjanee Kaliappan Shivee and Wana Ismail Normaz (2013). FDI and Economic growth: Empirical evidence from Southern Africa Customs Union (SACU) countries. www.semanticsholar.org.

xxxvii. Nguyen, D., T., Anh, and C. Phuong (2012). On the linkage between FDI and Trade: Evidence from Vietnam SECO/ WTI Academic Cooperation Project Working paper series

xxxviii. Nteegah, A. and G. E. Okpoi (2017). External trade and its implications on foreign reserves in Nigeria. West African Journal of Industrial and Academic Research, Vol 17, No 1 (2017)

xxxix. Obadan Mike I. (1982). Direct foreign investment in Nigeria: An empirical Analysis African Studies Review Vol.25 No1, pp.67-81

xl. OECD (2002). OECD publication reviews the role of FDI in Development. 26 September 2002 OECD Centre.

xli. Okon joseph Umoh, Augustine OkonJacob and Chuku A. Chuku (2012). FDI and economic growth in Nigeria: An analysis of the endogenous effects. Semanticscholar.org

xlii. Pefferman Guy P and Andrea Madarassy (1992). Trend in Private investment developing countries. Working papers from World Bank- International Finance Corporation

xliii. Reisen Helmut and Marcelo Soto (2001). Which types of capital inflows foster developing country growth? https:/ / www.blackwell-synergy.com/ servlet/ useragent. econpaer

xliv. Romer Paul (1990). Endogenous Technological Change. Journal of Political Economy vol 98, No. 5

xlv. Sakyi, D. and Egyir, J. (2017). Effects of trade and FDI on economic growth in Africa: an empirical investigation tandfonline.com, https:// doi.org/ 10.1080/ 19186444.2017.1326717

xlvi. Sakyi, D.; R. Commodore, and E. E. O. Opoku (2015). FDI, trade openness and Economic growth in Ghana: An empirical investigation Journal of African Business Vol. 16 Iss 1-2

xlvii. Simionescu, M. (2014). The relationship between trade and FDI in G7 countries a panel data approach. Journal of Economics and Development Studies, Vol 2, No 2, ppp. 447-454

xlviii. Smarzynska Beata K. (2002). Does FDI increase productivity of domestic firms: in search of spillovers through backward linkages? Policy research Working papers series 2923 The World Bank

xlix. Stefanovic Suzana (2008). Analytical framework of FDI determinants: implementation of the OLI model Facta Universitatis Economics and Organization Vol. 5 No3, 2008, pp.239-249 UDC 339.727.22

l. Tam Bang Vu (2008). FDI and endogenous growth in Vietnam. Journal of Applied Economics Vol. 40 (2008). Iss. 9 https:/ / doi.org/ 10.1080/ 00036840600749433

li. UNCTAD (2000). World Investment Report 2000: Cross-border Mergers and Acquisitions and Development. United Nations, New York and Geneva, 2000

lii. UNCTAD Report (2019). World investment report 2019. Special Economic Zones

liii. Watchel Paul (2003). How much do we really know about growth and finance. Economic Review Federal Reserve Bank of Atlanta

liv. Zaman, Q. U., Z. Donghui, G. Yasin, S. Zaman, M. Imran (2018). Trade openness and FDI inflows: A comparative study of Asian Countries. European Online Journal of Natural and Social Sciences

lv. Zhang Kevin Honglin (2001). How does foreign direct investment affect economic growth in China? Economics of Transition and Institutional Change Vol 9 Iss. 3.) January. https:/ / doi.or/ 10.1111/ 1468-0351.00095. 